\title{
30. SEISMIC STRATIGRAPHY IN THE BLAKE-BAHAMA BASIN AND THE ORIGIN OF HORIZON D 1
}

\author{
R. E. Sheridan and L. G. Bates, Department of Geology, University of Delaware, Newark, Delaware \\ T. H. Shipley, Geology Division, Scripps Institution of Oceanography, La Jolla, California \\ and \\ J. T. Crosby, Marine Seismology, Lamont-Doherty Geological Observatory, Palisades, New York
}

\begin{abstract}
Multichannel seismic reflection profiles in the area of the Blake-Bahama Basin reveal several prominent and widespread seismic horizons. Reflectors previously correlated by drilling include Horizon M, upper Miocene turbidites and debris flows; Horizon X, lower Miocene debris flows, turbidites, and fluidized grain flows; Horizon $\mathrm{A}^{\mathrm{u}}$, unconformity between lower Miocene and Eocene or Upper Cretaceous sediments; Horizon $\mathrm{A}^{\mathrm{c}}$, Eocene cherts; Horizon $\beta$, Barremian white turbiditic limestone; and Horizon $\mathrm{C}$, Tithonian red shaly limestone. A deeper sedimentary reflector observed just above basement throughout most of the Blake-Bahama Basin is Horizon D. This reflector had not been correlated by drilling prior to drilling at Site 534, which enabled us to correlate Horizon D with lower Oxfordian turbiditic limestones interbedded in dark green maroon shale and black shale.

Several newly identified reflection horizons have been named at Site 534. These are Horizons $\beta^{\prime}, C^{\prime}$, and $D^{\prime}$, all of which appear to be unconformities bounding sequences in which downlap occurs on apparently truncated beds below the hiatuses. The correlation of these unconformities at Site 534 includes Horizon $\beta^{\prime}$, lower Albian over upper Aptian; Horizon C', upper Berriasian over lower Berriasian; and Horizon D', Kimmeridgian over Kimmeridgian. There are no biostratigraphic indications of hiatuses across these horizons, unlike Horizon $\mathrm{A}^{\mathrm{u}}$, across which several stages are missing.

Horizon D apparently originates from widespread carbonate turbidites spreading across the Blake-Bahama Basin. These basin-leveling deposits extend seaward into the deepest topography of ancient fracture-zone troughs producing a fingerlike pattern of the Horizon D pinch-out. The basin-leveling turbidites overlie nonbasin-leveling reflectors that occur as asymmetric mounds draping the northern flanks of the fracture zones. These mounds are interpreted to be buried contourite deposits.
\end{abstract}

\section{INTRODUCTION}

Prior to 1975 , single-channel seismic reflection data from the Blake-Bahama Basin did not reveal the seismic stratigraphy below Horizon A (Markl et al., 1970; Sheridan et al., 1974). Apparently the small air-gun sound sources used on these early surveys did not produce enough energy to penetrate below the upper section, which was found by drilling at Site 391 to be highly cemented intraclastic chalks and limestones of the Miocene (Sheridan et al., 1978). The Miocene section has a relatively high seismic velocity of up to $2.5 \mathrm{~km} / \mathrm{s}$, which causes a higher reflectivity of input energy at a shallower depth than in more normal oceanic areas where the shallowest sediments have lower velocities of 1.6 to 1.8 $\mathrm{km} / \mathrm{s}$.

In 1975 the cooperative USGS-IFP multichannel seismic reflection survey from the Florence (Fig. 1) collected the first data that show the entire sedimentary section to basement in the Blake-Bahama Basin (Dillon et al., 1976). These data revealed several prominent reflectors between Horizon A and basement, one of which looked like Horizon $\beta$ and was thus identified prior to calibration by drilling.

The Florence profiles revealed that basement was within $6800 \mathrm{~m}$ total depth and therefore within the en-

\footnotetext{
${ }^{1}$ Sheridan, R. E., Gradstein, F. M., et al., Init. Repts. DSDP, 76: Washington (U.S. Govt. Printing Office).
}

gineering drill string limit of the Glomar Challenger. This information led to the drilling at Site 391 that was an unsuccessful attempt to reach basement in the BlakeBahama Basin. Mechanical failure of three reentry cones prevented the penetration of the oldest sediments in the basin and basement. However, drilling at Site 391 reached $1412 \mathrm{~m}$ sub-bottom and yielded the correlation of Horizon $\beta$ with the Barremian white limestones; this correlation is in agreement with other sites in the western North Atlantic. Below $\beta$, a prominent reflector called Horizon C by Sheridan et al. (1978) was also penetrated and was correlated with the top of Tithonian red shaly limestones. The drilling at Site 391 also confirmed the correlation of Horizon M (Dillon et al., 1976) with upper Miocene chalk turbidites and debris flows, as predicted by Sheridan et al. (1974). Horizon A in the BlakeBahama Basin was found at Site 391 to be the hiatus between the lower Miocene debris flow chalks and the Upper Cretaceous claystones, as it is elsewhere, and, thus, Horizon $\mathrm{A}$ is equivalent to Horizon $\mathrm{A}^{\mathrm{u}}$ of Tucholke and Mountain (1979).

Prior to drilling at Site 534, a 24-channel seismic reflection survey was made on Cruise 2102 of the Robert Conrad (Fig. 1). This survey provided a grid connecting Sites 534 and 391 and mapped the detailed basement relief between the two sites. This survey also showed that both sites, although only $22 \mathrm{~km}$ apart on the Blake-Bahama Basin abyssal plain, are over slight basement highs that flank a northwest-southeast-striking basement trough between the two sites. The trough is inter- 


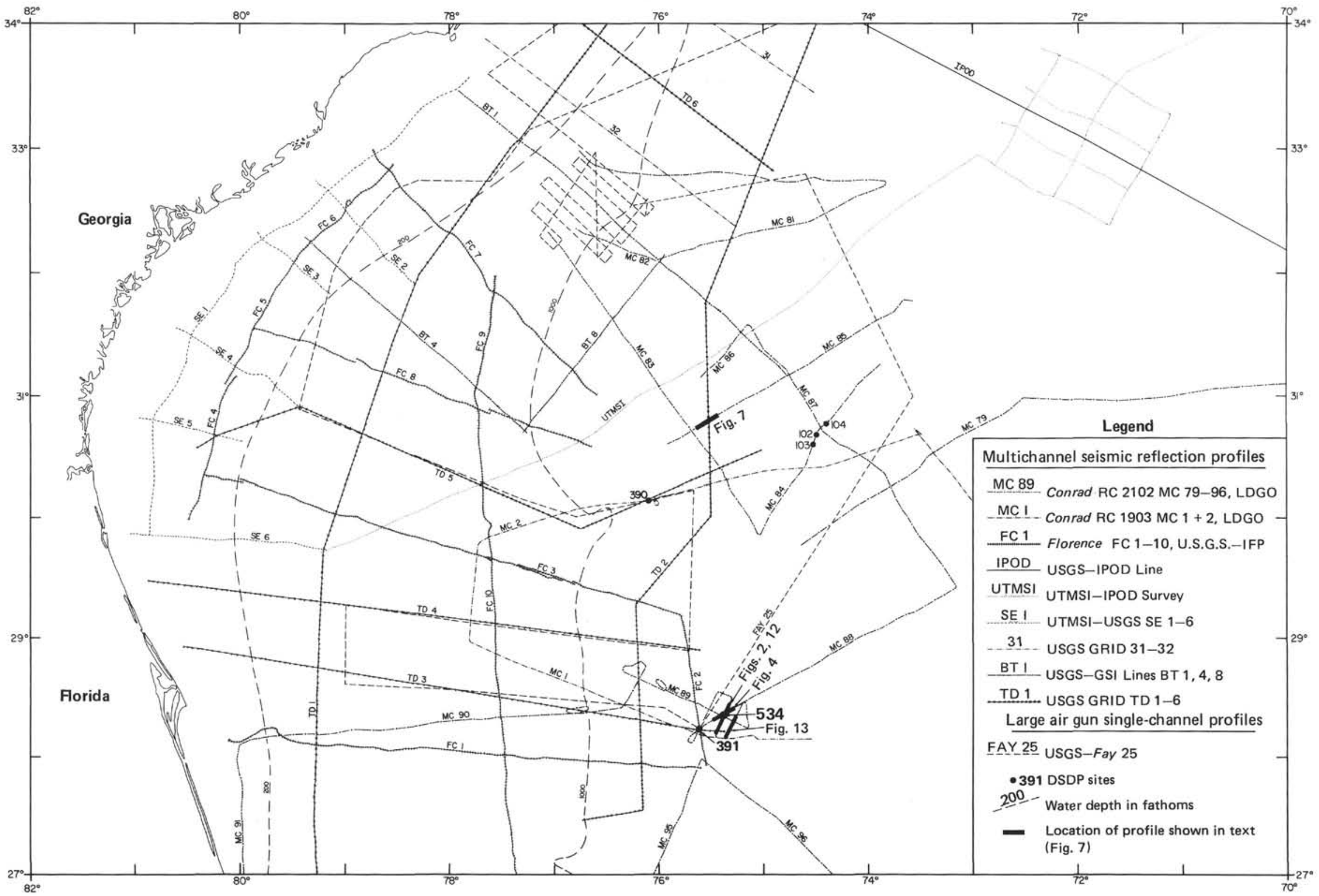

Figure 1. Location map of seismic surveys used to map Horizon D and seismic stratigraphy of the Blake-Bahama Basin. (Also located are DSDP Sites 534 and 391.$)$ 
preted to be a small fracture-zone valley filled in with an originally isolated pocket of sediments. Seismic interval-velocities measured with two orthogonal sonobuoys at Site 534 indicate that basement on the flanks of the trough was within the $6800-\mathrm{m}$ drill-string limit of Glomar Challenger; however, to reach basement in the center of the trough would require a total drill string of about $7200 \mathrm{~m}$. This is beyond Challenger's capability. Consequently, Site 534 was chosen on the northeast flank of the fracture-zone trough. This placement of Site 534 also was necessitated by the potential confusion of the new reentry cone with the three malfunctioned cones at Site 391. Occupation of a site on the southwest flank of the fracture-zone trough near Site 391 would have been fraught with problems of cone identification.

The Conrad Cruise 2102 site survey was designed to take advantage of additional multichannel seismic reflection profiles available in the Blake-Bahama Basin. Many tracks have been completed since the original Florence survey that made lines FC 1, 2, and 3 in 1975 (Fig. 1). Although not part of the site-specific grid done on Conrad Cruise 2102, many additional, good quality seismic lines had tied into Site 391 subsequent to 1975 when holes were drilled there. Now the available seismic reflection data include many thousands of kilometers of high quality, large-energy-source data that show the basement and complete sedimentary section (Fig. 1). These incorporate the separate data sets from various organizations, such as Lamont-Doherty Geological Observatory (L-DGO) Robert Conrad Cruises RC 1903 (MC 1, 2) and RC 2102 (MC 79-96) (Sheridan et al., 1979; Bryan et al, 1980; Sheridan et al., 1981); Institute Français du Petrole (IFP) Florence cruise (FC 1-10) (Dillon et al., 1976; 1979); U.S. Geological Survey (USGS) Teledyne contract survey (TD 1-6) (Paull and Dillon, 1980), the Fay survey (Klitgord and Grow, 1980), and Geophysical Services Incorporated (GSI) exclusive data (BT 1, 4, and 8) (Dillon et al., 1979); Inter- national Phase of Ocean Drilling Site Survey Management (IPOD line) (Grow and Markl, 1977); and the University of Texas Marine Science Institute (UTMSI) Blake Plateau surveys (SE 1-6, Buffler et al., 1979; and UTMSI 2, Shipley et al., 1978) and the IPOD site survey (Shipley and Watkins, 1978).

The Conrad site survey in the Blake-Bahama Basin added two new reflector nomenclatures to the seismic stratigraphy (Bryan et al., 1980). Ties through the RC 2102 lines MC 79-96 showed that Horizon X, as originally defined by Markl et al. (1970) under the Blake Outer Ridge, correlated with middle to lower Miocene debris flow units at Site 391. In addition, the deepest sedimentary seismic reflector just above basement was mapped as a continuous unit over most of the area. This was named Horizon D by Bryan et al. (1980).

All of the deeper seismic horizons, including $A^{u}, \beta$, C, D, and basement have been cored at Site 534 (Fig. 2). This chapter will discuss the origin of the seismic stratigraphy in relation to the development of the North American continental margin, and the calibration and testing of these seismic interpretations at Site 534 .

\section{SEISMIC CORRELATION AT SITE 534}

Only the section below $545 \mathrm{~m}$ sub-bottom depth was continuously cored at Site 534, because the surface conductor and casing were set to $531 \mathrm{~m}$ sub-bottom. At that depth the harder cemented chalks and limestones were able to support the casing. These harder sedimentary units lie just beneath Horizon $\mathrm{X}$ as tied from the Blake Outer Ridge (Fig. 3). Consequently, we believe the impedance contrast causing X was not sampled at Site 534 . Horizon X, however, is correlated with the boundary between Units $2 \mathrm{~d}$ and $2 \mathrm{e}$ at Site 391 in the Great Abaco Member, on the basis of the work of Bryan et al. (1980), Sheridan et al. (1978), Benson et al. (1978), and Jansa et al. (1979). Similarly, Horizon M was not cored at Site 534, being at the level where casing was set, so its corre-

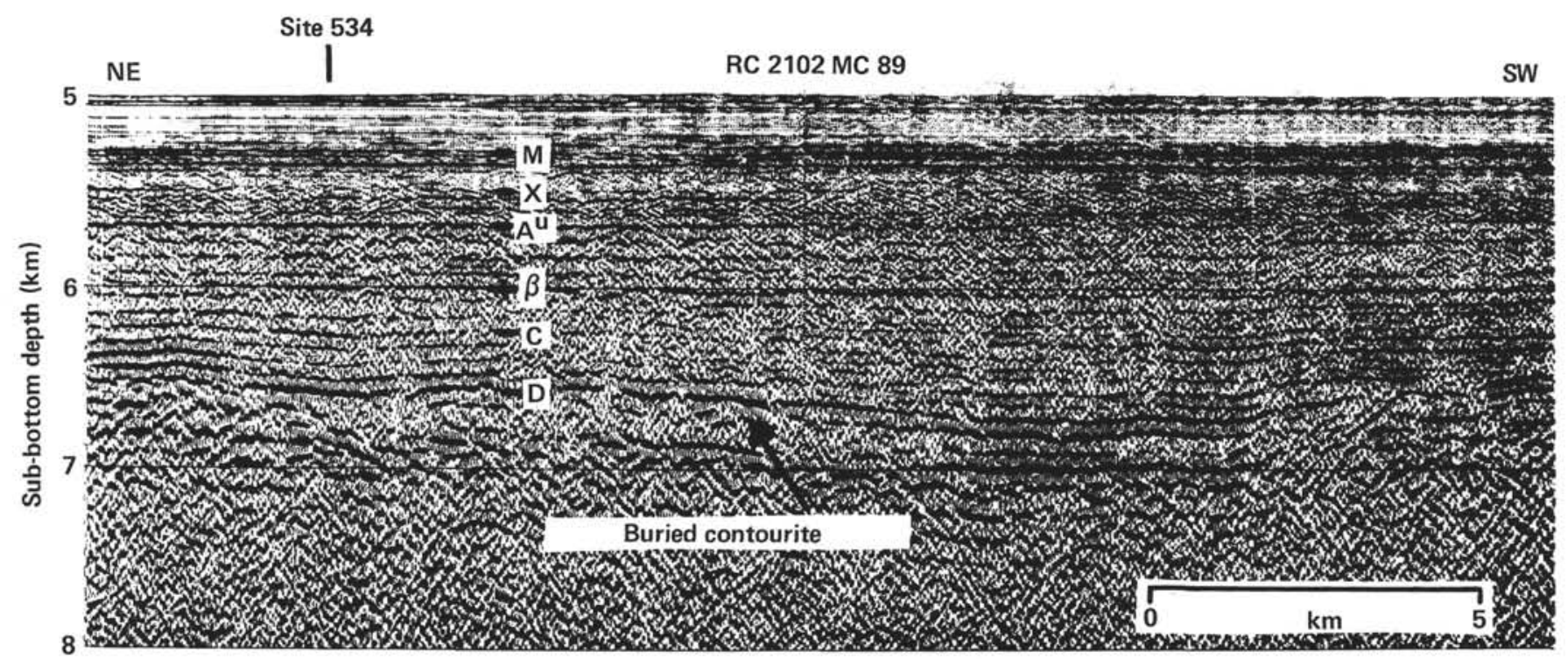

Figure 2. Portion of multichannel seismic reflection profile MC 89 made from the Robert Conrad near Site 534. (Seismic Horizons M, X, $\mathrm{A}^{\mathrm{u}}, \beta, \mathrm{C}$, and $\mathrm{D}$ are noted, as are some reflectors interpreted to be buried contourites in the D to basement interval. Location of profile is shown in Fig. 1.) 


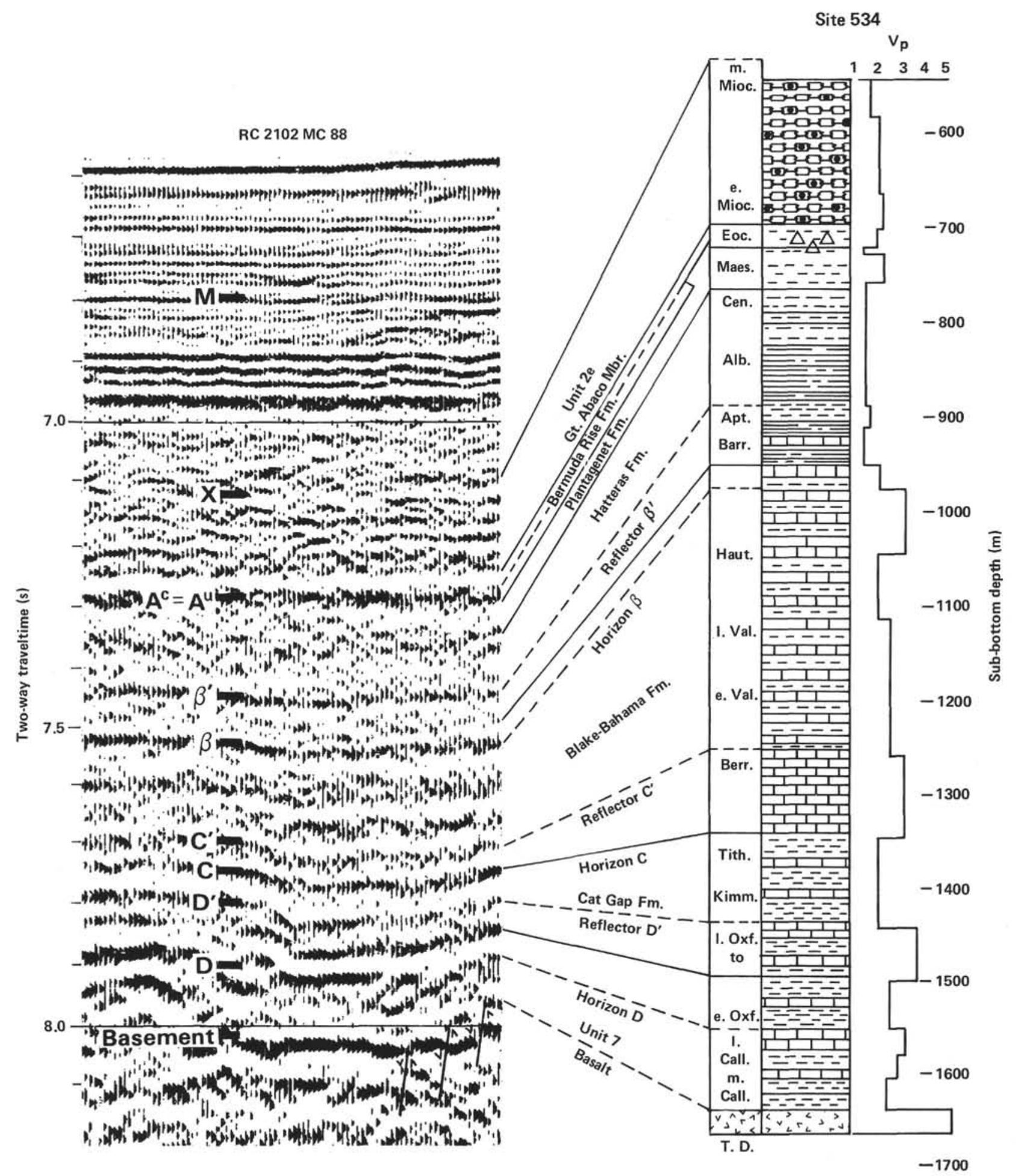

Figure 3. Correlation of seismic reflection profile near Site 534 with drilling results. (The solid correlation lines identify formation boundaries, the dashed correlation lines identify correlations of seismic reflections horizons. Formation nomenclature is after Jansa et al. [1979]. Also shown is the compressional wave seismic velocity in $\mathrm{km} / \mathrm{s}$ measured on the cores on board Challenger [Site 534 report, this volume].)

lation relies on the past work at Site 391. There Horizon $\mathrm{M}$ is correlated with upper to middle Miocene intraclastic chalks, turbidites, and debris flows (Sheridan et al., 1978; Jansa et al., 1979).

One surprising correlation found at Site 534 was that the seismic wavelet correlated with Horizon $\mathrm{A}^{\mathrm{u}}$ at Site
391 appears to merge with the seismic Horizon $\mathrm{A}^{\mathrm{c}}$, which is correlated elsewhere with Eocene chert and porcellanite beds (Tucholke and Mountain, 1979). The evidence that $A^{c}$ is present is the surprising discovery of a thin layer of Eocene porcellanite and zeolitic claystones at a sub-bottom depth of $719 \mathrm{~m}$. This small layer 
of the Bermuda Rise Formation (Fig. 3) might be a lenslike remnant of a previously more extensive formation that was eroded during the late Eocene to Oligocene. Thus this geological evidence indicates that the seismic Horizon $\mathrm{A}^{\mathrm{c}}$ is following such a thin geological unit that its wavelet is merged by convolution interference with the $\mathrm{A}^{\mathrm{u}}$ reflection. The Horizon $\mathrm{A}^{\mathrm{u}}$ reflection correlates with the major unconformity between the lower Miocene and Eocene or older beds, such as at Sites 391 and 101.

Below Horizons $\mathrm{A}^{\mathrm{u}}$ and $\mathrm{A}^{\mathrm{c}}$, there are the claystones of the variegated Plantagenet Formation and of the carbonaceous Hatteras Formation. These formations, both being claystones, are not separated by a marked seismic horizon. On the other hand, the Hatteras Formation passes downward through a gradational zone into the massive, turbiditic white limestone of the Blake-Bahama Formation. The shallowest massive turbiditic limestone at $975 \mathrm{~m}$ sub-bottom is correlated with Horizon $\beta$. The Barremian age of this reflector at Site 534 agrees very well with the age of Horizon $\beta$ correlated at Site 391 and at other sites in the western North Atlantic (Sheridan et al., 1978; Benson et al., 1978; Jansa et al., 1979).

Another correlation that is in agreement with those of Site 391 is the identification of Horizon C as the top of the Cat Gap red limestone at Site 534. This transition to the Cat Gap Formation from the Blake-Bahama For- mation occurs at $1342 \mathrm{~m}$ in Tithonian beds. This is identical to the age of Horizon C correlated at Site 391 (Sheridan et al., 1978; Benson et al., 1978; Jansa et al., 1979).

Three newly defined seismic horizons are identified at Site 534 (Fig. 3). These are Horizons $\beta^{\prime}, C^{\prime}$, and $D^{\prime}$. All three are different datums than the previously defined Horizons $\beta, \mathrm{C}$, and D. Also, all three of these horizons show evidence of a physical hiatus, indicated by reflection terminations as truncations from below or downlaps from above (Fig. 4). Moreover, at all three horizons the drilling indicates both sharp drilling rate breaks and lithologic changes, rather than gradational facies changes. These occurrences support the seismic data that indicate the presence of unconformities. On the other hand, the biostratigraphic resolution is such that no significant hiatuses are documented at these boundaries. This is unlike Horizon $\mathrm{A}^{\mathrm{u}}$, which correlated well with the drilled hiatus between lower Miocene and Eocene rocks.

Horizon $\beta^{\prime}$ is correlated with the orange-colored claystone between the lower Albian and upper Aptian rocks at $880 \mathrm{~m}$ sub-bottom. The orange to red clays are compatible with an interpretation of low net-sedimentation caused by current scour and possible bypassing of fine-grained sediments. Shipley and Watkins (1978) report a seismic unconformity close to the position of Horizon $\beta$ well to the north of Cape Hatteras. Although

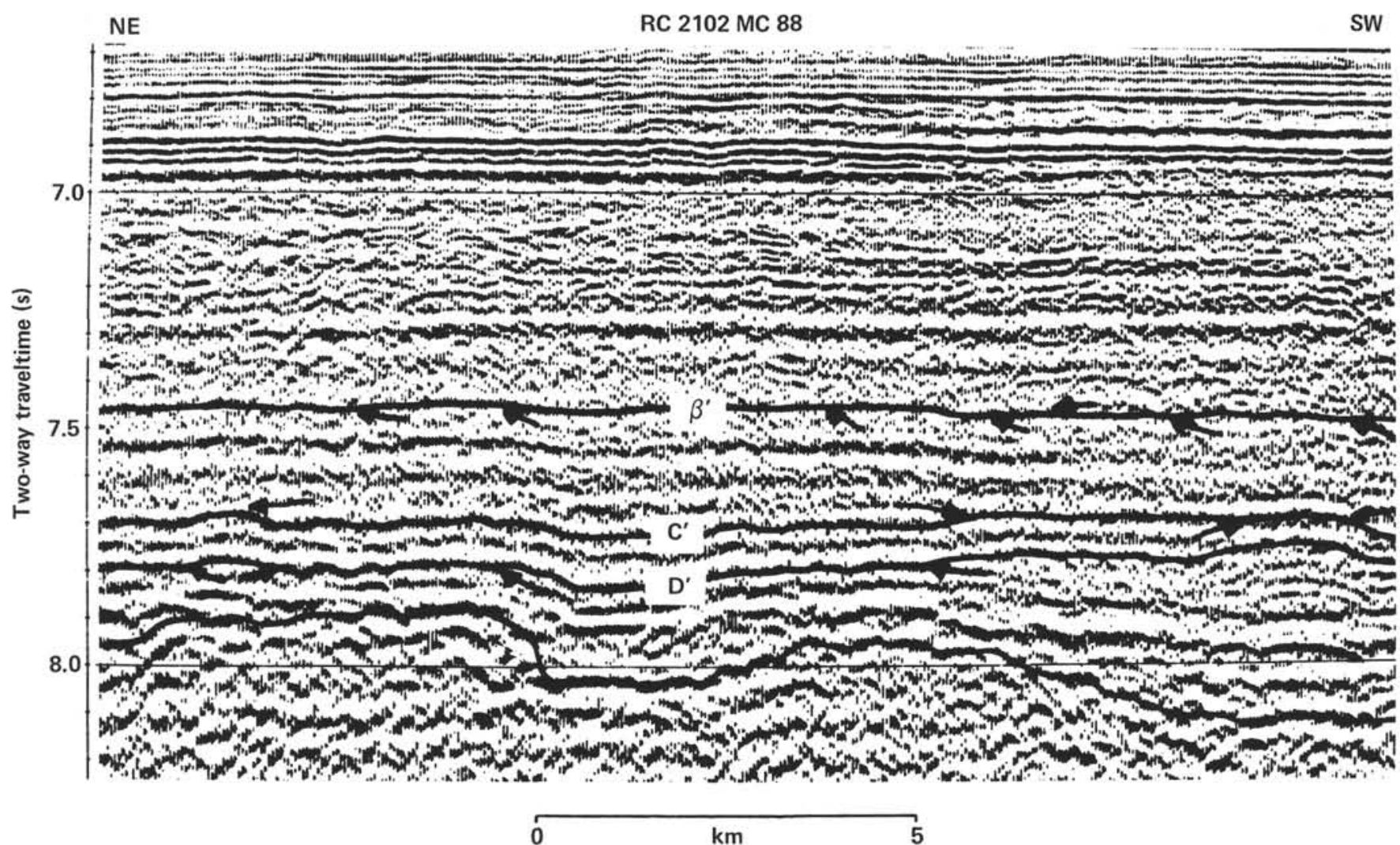

Figure 4. Portion of multichannel seismic reflection profile MC 88 made from the Robert Conrad near Site 534. (Reflector terminations on Horizons $\beta^{\prime}, C^{\prime}$, and D' are indicated. This profile has been deconvolved with a Burg-type operator, and has time-variable filtering and gain. Location is shown in Fig. 1.) 
we have not carried out a correlation by physical ties, it is suggested here that these are one and the same unconformity.

Horizon $C^{\prime}$ is correlated at Site 534 with the abrupt boundary between the limestones and claystones and the massive turbiditic limestones at a depth of $1250 \mathrm{~m}$. This is within the Berriasian and might be equivalent to the basal-Valanginian (131 m.y.) unconformity suggested by Vail et al. (1980) on the UTMSI profile across the Blake Outer Ridge. On several reflection profiles across the Blake Escarpment (Shipley et al., 1978; Paull and Dillon, 1980) there is an areally restricted seismic unit forming a wedge that downlaps on a possible Horizon $\mathrm{C}^{\prime}$ equivalent. This downlap indicates that Horizon $\mathrm{C}^{\prime}$ might be a nondepositional hiatus.

At Site 534 Horizon $\mathrm{D}^{\prime}$ correlates with an abrupt drilling break between the red claystones and the turbiditic limestones at $1442 \mathrm{~m}$. This is within the Kimmeridgian Cat Gap Formation and might well be the unconformity proposed for this age (141 m.y.) by Vail et al. (1980). Marked truncations are evident at this horizon, indicating that it is a sequence boundary (Fig. 4).

The deepest sedimentary reflector at Site 534 that is mappable as a prominent marker is Horizon D (Fig. 3). It is mapped as a reflector just above basement throughout most of the Blake-Bahama Basin (Bryan et al., 1980; Sheridan et al., 1981). It was clear from past analysis of the seismic stratigraphy in the Basin that Horizon D and the underlying D to basement sediment interval had never been penetrated by previous drilling. Accordingly, Horizon D was felt to mark the top of yet unknown sediments, older than the previously drilled Cat Gap Formation penetrated at Sites 105, 100, 99, and 391 (Jansa et al., 1979). Penetration through these oldest sediments and into oceanic basement were the objectives of Site 534, and these were successfully completed. Horizon D is correlated with turbiditic limestones interbedded with the dark green and maroon claystone at $1550 \mathrm{~m}$. This horizon is within the upper part of a newly discovered lithology that has yet to be named as a formal formation. Now it is referred to as the unnamed Unit 7. The age of Horizon D is early Oxfordian.

The basaltic rocks of oceanic basement were found at $1635 \mathrm{~m}$ sub-bottom only $85 \mathrm{~m}$ beneath Horizon D. These rocks are intercalated with red and green claystones of the unnamed unit; these claystones are no older than the middle Callovian. The basement shows up as a prominent well-defined reflector with the typical hyperbolic character normally observed in areas underlain by oceanic crust (Figs. 2 and 3).

Synthetic seismogram modeling of a constructed impedance $\log$ for Site 534 was completed by Shipley (this volume). Unfortunately these models are not able to verify uniquely these correlations as made on board Challenger and presented here. This is because there are significant uncertainties about the representative nature of the laboratory velocities used in Shipley's models, and these velocities are the main bases for the model computations. The correlations presented here, however, considered not only the velocity measurements made on board, but sonobuoy velocity data, drilling rate logs, and the density logs as well.

Correlation of these Horizons $\mathrm{A}^{\mathrm{u}}, \beta, \mathrm{C}$, and $\mathrm{D}$ and mapping these landward into the continental margin indicate good continuity with reflectors that are tied to coastal wells (Figs. 5 and 6). Although there is always a gap in the quality of the seismic reflector data along the Blake-Bahama Escarpment, caused by diffractions from the steep Escarpment and by abrupt facies variations of the bank edge, plausible geological correlations can be made between the well tied reflections under the Blake Plateau and the Bahamas and the reflection horizons in the Blake-Bahama Basin. All the Upper Jurassic and younger seismic horizons that have been drilled at wells, such as the Great Issac Well in the Bahamas (Fig. 6), may thus be geologically correlated. It is interesting that a yet undrilled seismic unit under the Bahamas may represent Middle Jurassic rocks. This unit continued seaward in a simple manner to correlate with Horizon D in the Blake-Bahama Basin, which is near the top of the Middle Jurassic (Fig. 6). This indicates that the correlation of Horizon D at Site 534 supports the interpretation that there are Middle Jurassic sedimentary rocks under the Bahamas, a fact that has important paleoceanographic implications. For example, this fact is important for dating the marine connections between the Atlantic Ocean and Gulf of Mexico that Salvador and Green (1980) feel did not occur until the Late Jurassic.

\section{EXTENT OF HORIZON D}

In the area of the Blake-Bahama Basin, Horizon D is the reflector just above basement (Figs. 5 and 6). However, to the northwest and southwest the $\mathrm{D}$ to basement interval thickens abruptly both landward of the Blake Spur basement escarpment and ridge and landward of the basement structures of the Great Abaco fracture zone. There is a distinct structural trough along the base of the Blake-Bahama Escarpment in which the D to basement interval thickens. Seaward of the Blake Spur basement ridge, the thickness of the $\mathrm{D}$ to basement interval is much less north of the Blake Spur fracture zone than south of the fracture zone, and this interval is more often trapped landward of the ridge (Fig. 7).

Based on the seismic profiles, the sediments just beneath Horizon $\mathrm{D}$ are apparently a basin-leveling event and were interpreted as distal turbidites even before drilling at Site 534. For some geologic time interval the basement ridge along the Blake Spur magnetic anomaly (Figs. 7, 8, and 9) acted as a dam to these turbidites. In the early Oxfordian, carbonate turbidites forming Horizon D breeched the dam, especially along the deeper fracture-zone troughs. Distal carbonate turbidites then spread as far seaward as they could along fracture-zone troughs to the crestal area of the then-existent midocean ridge, forming the fingerlike pinch-out pattern. This interpretation agrees with the isopach map of the Horizon D to basement sediment interval (Fig. 9). The greatest thickness ( $>1.25 \mathrm{~s}$ two-way traveltime) is west of the Blake Spur anomaly ridge. The damming effect of this ridge drastically reduced the thickness seaward of 
Line MC 90

Line MC 89

Blake Plateau

Blake-Bahama Basin

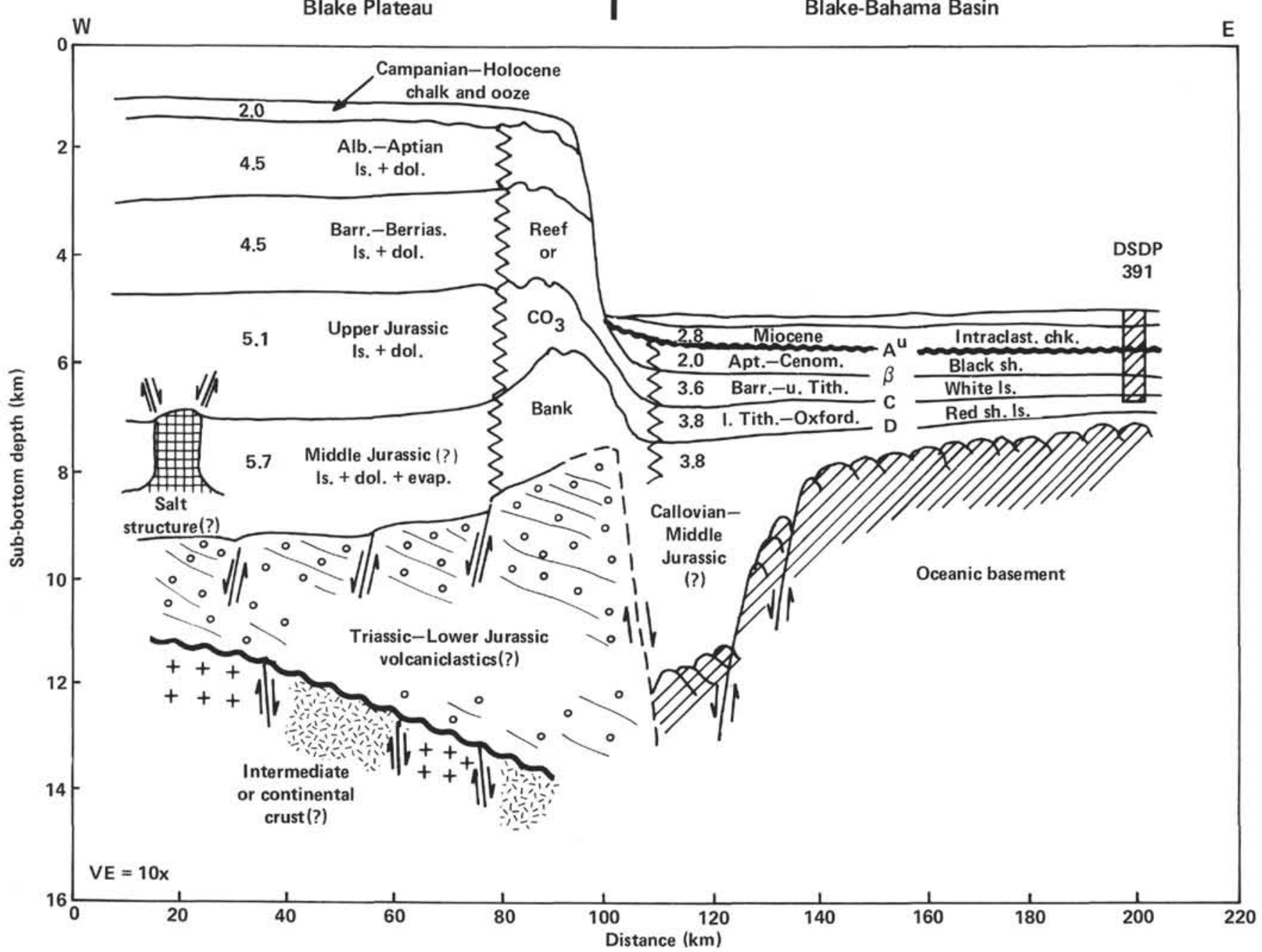

Figure 5. Depth section across the Blake Escarpment and Blake-Bahama Basin based on multichannel seismic profiles MC 89 and 90 (Sheridan et al., 1981).

the Blake Spur anomaly where the maximum thicknesses are in the fracture-zone troughs such as between Sites 391 and 534 ( $>0.25 \mathrm{~s}$ two-way traveltime).

To convert this isopach to true thickness requires some assumptions about the interval velocities for the D to basement interval. On the basis of sonobuoy measurements during the site survey, Bryan et al. (1980) found velocities as high as $3.4 \mathrm{~km} / \mathrm{s}$ for this layer. However, upon drilling at Site 534 the claystones of this interval were found to have velocities of only approximately $2.5 \mathrm{~km} / \mathrm{s}$. These lower velocities are probably more representative because the $3.4-\mathrm{km} / \mathrm{s}$ velocity was measured by refraction waves along the turbiditic limestones forming Horizon D. These turbidites have high seismic velocities $(3.0-3.5 \mathrm{~km} / \mathrm{s})$ when measured in the ship's laboratory at Site 534 (Shipley, this volume). Assuming the $2.5 \mathrm{-km} / \mathrm{s}$ velocity for sediments seaward of the Blake Spur ridge implies that pockets of sediments of the D to basement interval are more than $250 \mathrm{~m}$ thick.

Landward of the Blake Spur magnetic anomaly, the velocity is only known remotely from sonobuoy and
CDP (common depth point) velocity analyses; it ranges from 3.4 to $5.0 \mathrm{~km} / \mathrm{s}$. This range is reasonable when compared to the seismic reflection character of the D to basement interval (Fig. 7). The marked stratification and basin-leveling character seem to imply a turbiditic origin of more proximal carbonate turbidites. If this velocity is correct, then thickness of the $\mathrm{D}$ to basement interval is in excess of $2500 \mathrm{~m}$.

Another important result from the mapping of Horizon $\mathrm{D}$ is the correlation of this reflector, originally named in the Blake-Bahama Basin (Bryan et al., 1980), with the reflection Horizon $\mathrm{J}_{2}$, originally named by surveys off Cape Hatteras (Klitgord and Grow, 1980). The recent high quality tie lines, such as TD 2 and MC 87 and 88 (Fig. 1), strongly indicate that Horizon D is equivalent to Horizon $\mathrm{J}_{2}$, which agrees with the correlation previously made by Paull and Dillon (1980). The distribution and pinch-outs of these seismic horizons support this identification. For example, Horizons C and $\mathrm{J}_{1}$ can be mapped in pockets just above basement as far seaward as Magnetic Anomaly M-23 (Sheridan et al., 1978; Tucholke and Mountain, 1979; Klitgord and 


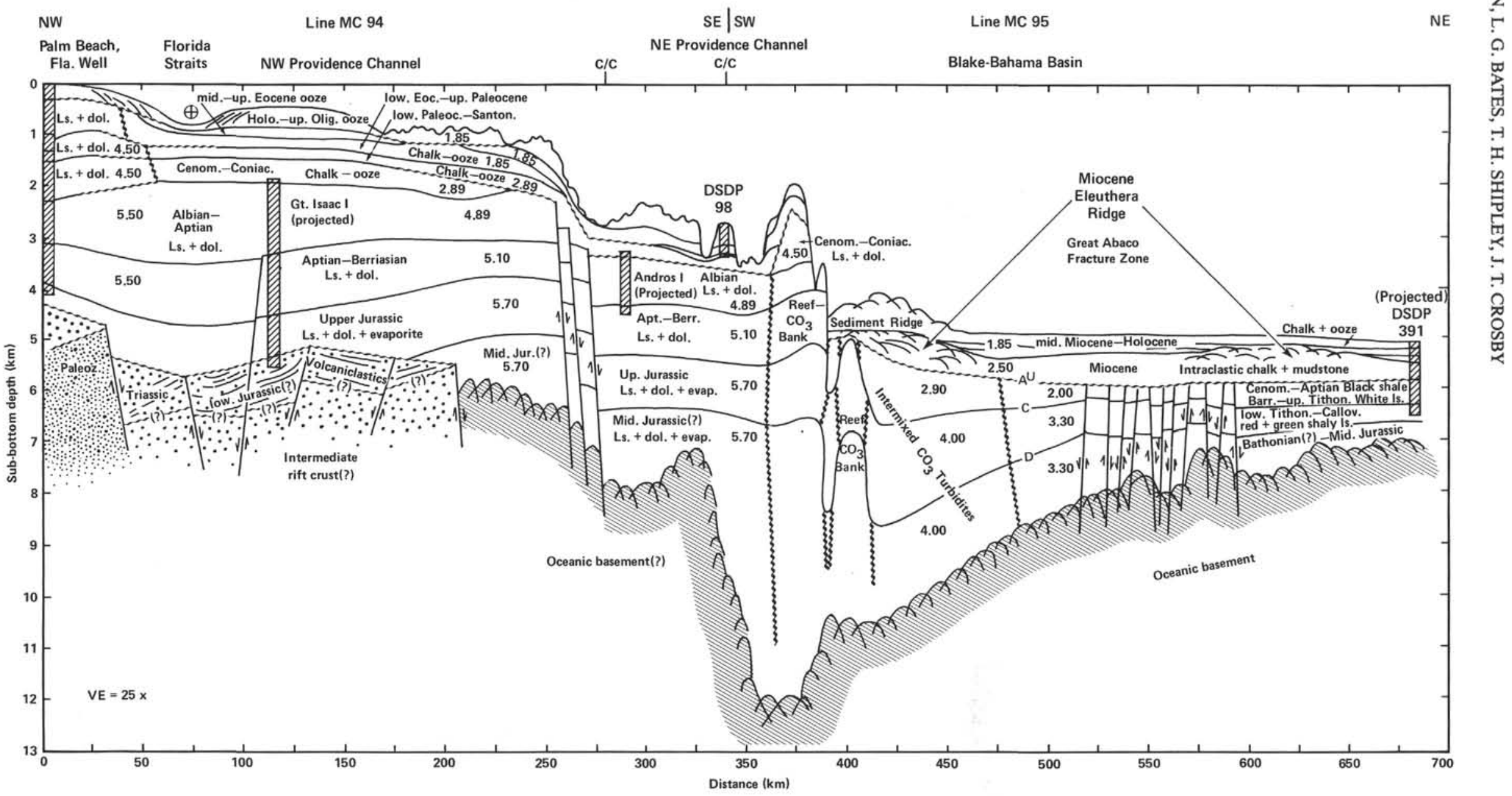

Figure 6. Depth section across the Bahama platform and Blake-Bahama Basin based on multichannel seismic profiles MC 94 and 95 (Sheridan et al., 1981 ). 


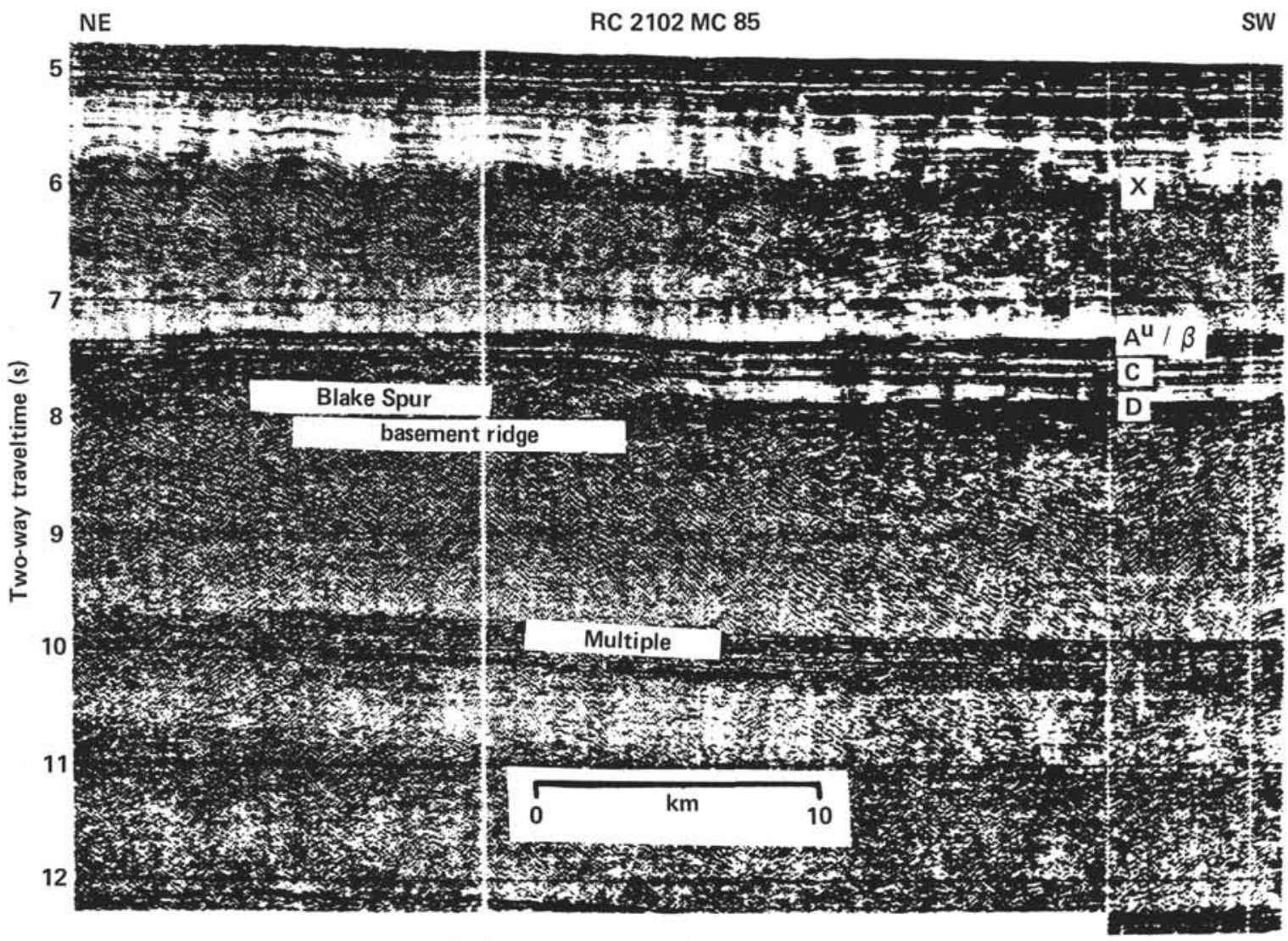

Figure 7. Portion of multichannel seismic reflection profile MC 85 showing the basement ridge under the Blake Spur magnetic anomaly and the apparent trapping of Horizon D west of this ridge. (Location is shown in Fig. 1.)

Grow, 1980), which is seaward of Sites 105 and 100 where the Kimmeridgian-Oxfordian Cat Cap Formation was found resting on oceanic basement. Now at Site 534 the unnamed Unit 7, which contains Horizon $\mathrm{D}$, is found to be a clearly older Callovian and is composed of a totally different lithofacies than the Cat Gap Formation. Thus the drilling at Sites 100,105 , and 534 indicates that the sediments beneath Horizon D do not extend as far seaward as Sites 100 and 105 .

This fact is important, because the reflector that this paper identifies as Horizon D in the Blake-Bahama Basin had in the past been incorrectly correlated by Mountain (1981) with a prominent reflector just above basement near Sites 100 and 101. Because this prominent reflector is equivalent to Horizon $J_{1}$ (Horizon C) (Sheridan et al., 1978), the maps of Mountain (1981) show no $\mathrm{J}_{2}$ to basement unit in the Blake-Bahama Basin at Site 534 , but rather show the sediments beneath $J_{1}$ lying directly on basement. Mountain's (1981) maps imply that the Cat Gap Formation, the $\mathrm{C}\left(=\mathrm{J}_{1}\right)$ to basement unit at Sites 100 and 105, should overlie basement at Site 534 and that the older formation beneath Horizon D $\left(=J_{2}\right)$ would not be present there. However, the successful recovery of the new unnamed formation at Site 534 is good supporting evidence that the extent of Horizon D, as shown in Figure 8, is correct. This is because this new formation causes the next significant seismic boundary beneath Horizon $J_{1}$ in the western
North Atlantic basin. Thus Horizon $\mathrm{J}_{2}$ should be expected to occur in the Blake-Bahama Basin at Site 534.

Jansa et al. (1979) indicate that the major seismic reflection horizons in the western North Atlantic correlate closely to boundaries of the formations, which are strong impedance contrasts in most cases. Because the western North Atlantic basin environment was uniform over a wide basinal area, and the changes in regional environment were relatively rapid, the facies changes associated with the environmental changes occurred relatively rapidly. Consequently, the lithofacies boundaries of the formations are nearly bedding planes or time stratigraphic horizons over the wide basinal area. If this is so, then Horizon D represents the new formation and is probably of nearly the same age throughout the basin. This would explain why the fingerlike pinch-out limit of Horizon D is consistent along strike in the western part of the outer Jurassic magnetic quiet zone (Fig. 8). The pinch-out more or less follows a magnetic anomaly isochron.

Another factor related to the time stratigraphic significance of Horizon D is its turbiditic origins. Why should a turbidite facies be time equivalent over a wide area of a basin? Probably because the global eustatic sea-level changes occurring during Horizon D time, the early Oxfordian, were at a particular stage that favored the generation of turbidites in the carbonate bank source areas rimming the western North Atlantic basin. 


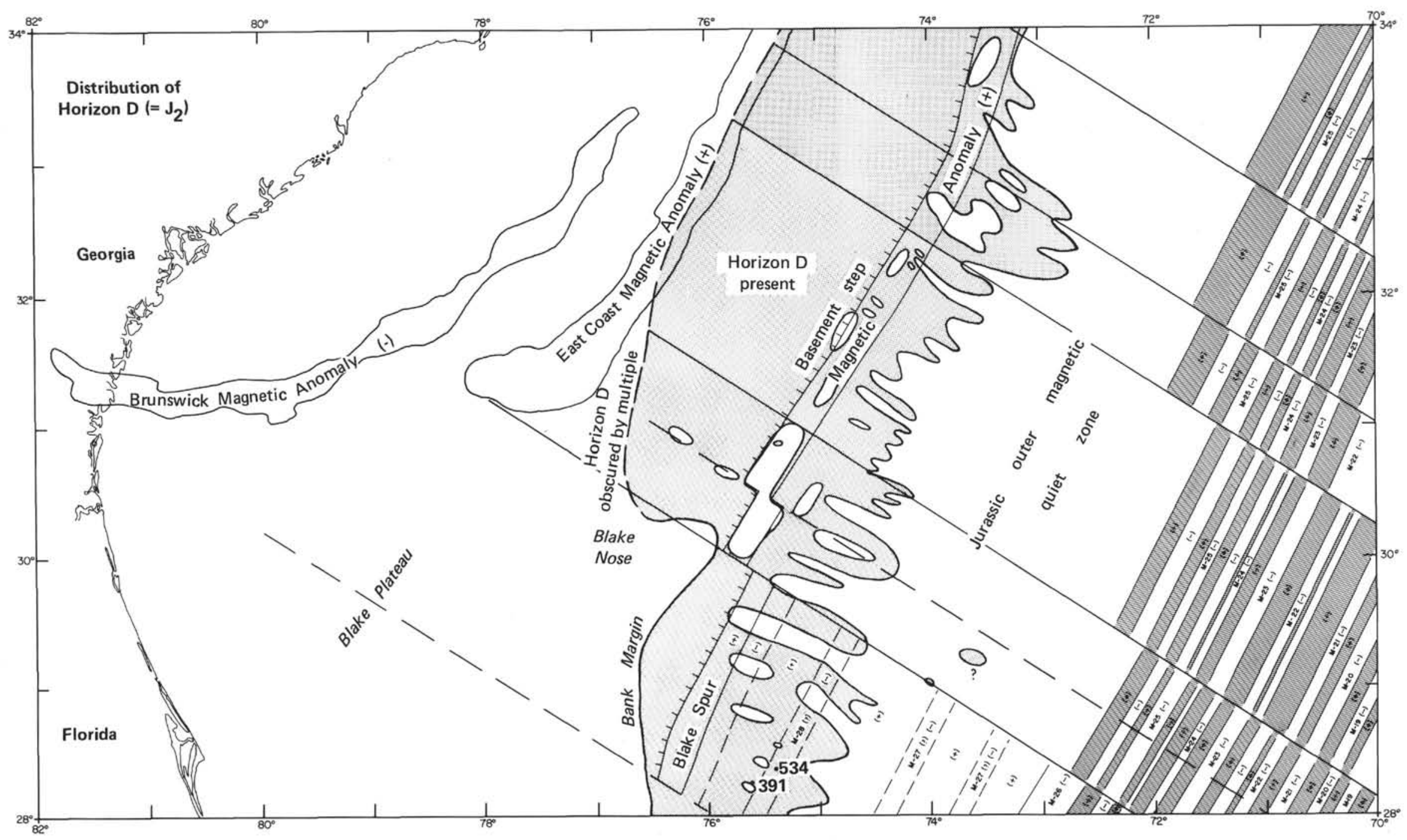

Figure 8. Subcrop map of extent of Horizon D, which is correlated with Horizon $\mathrm{J}_{2}$. (Also shown is the position of the Blake Spur magnetic anomaly and the associated basement ridge or step.) 


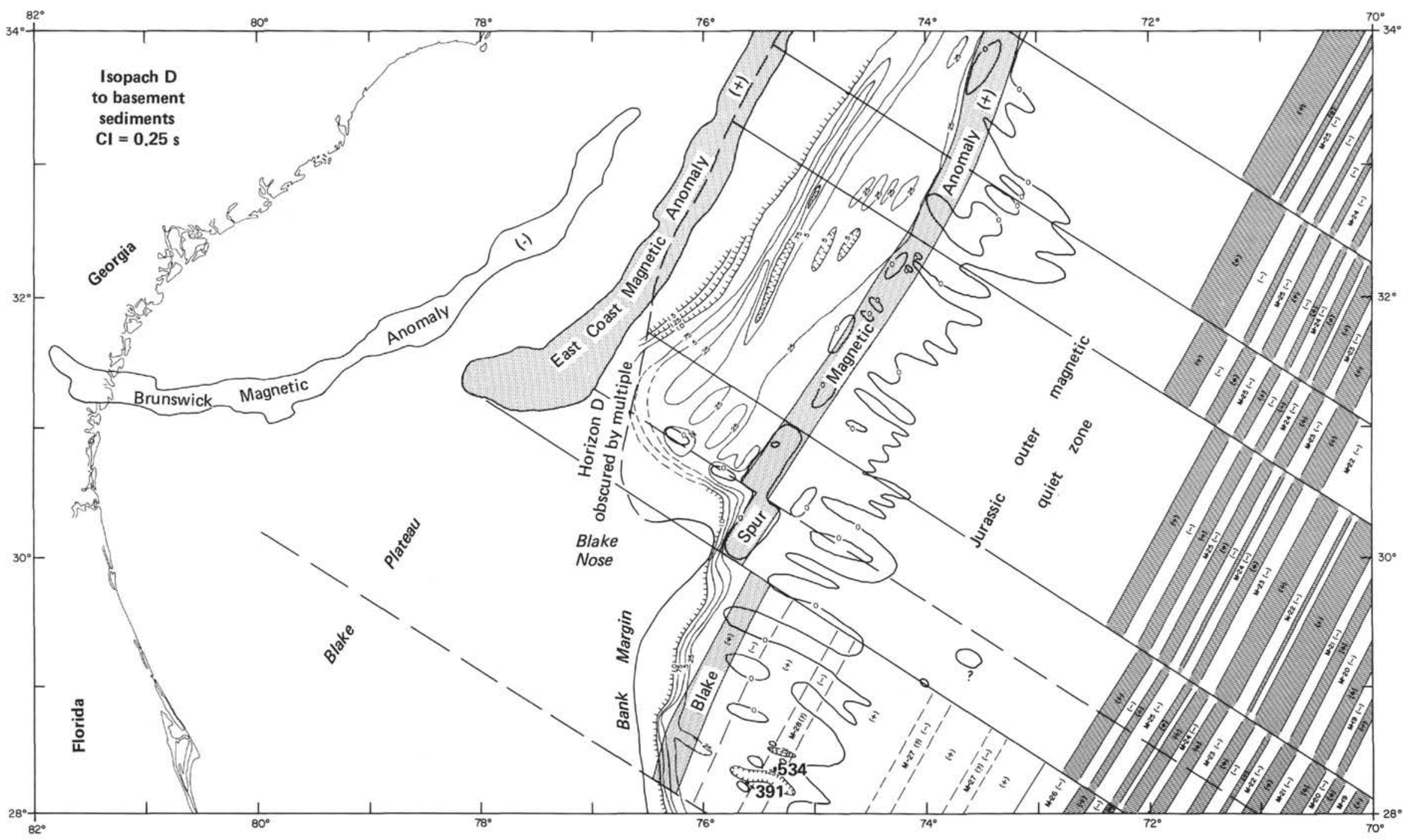

Figure 9. Isopach map of the Horizon D to basement interval in seconds of two-way traveltime. (Seaward of the Blake Spur anomaly the contour interval [CI] equals approximately $250 \mathrm{~m}$; landward of the anomaly, the contour interval is approximately $500 \mathrm{~m}$, based on interval velocity estimates from sonobuoy and CDP velocity analyses.) 
The early Oxfordian was a time of a major sea-level rise and is thought to have generated excess loose carbonate sediments. This contrasts with sea-level falls, when carbonate banks are exposed to subaerial karstic solution, and the clastic source is shut down.

\section{EVIDENCE FOR CONTOURITES BENEATH HORIZON D FROM SEISMIC FACIES INTREPRETATION}

Interpretation of the site survey data near Site 534 indicated that the seismic reflection character of the $\mathrm{D}$ to basement interval is noticeably different than that of the overlying units (Fig. 2). Whereas the overlying reflectors, especially $\beta, \mathrm{C}$, and $\mathrm{D}$, are flat-lying and onlapping in character, the internal reflectors of the $\mathrm{D}$ to basement unit are hummocky and asymmetrically draped on the flanks of basement highs (Fig. 2). This distinctly nonbasin-leveling character appears to occur in an acoustically transparent section beneath the very stratified $\beta$ to $D$ units. Also, this transparent unit changes facies laterally southward into well stratified channel-floor deposits in the center of the basement trough. Moreover, the occurrence of draping and mounding against basement in the $\mathrm{D}$ to basement interval was found in three profiles to be consistently on the north side of basement troughs with fracture-zone trends, that is, troughs striking northwest-southeast (Fig. 9).

These factors were taken into consideration in making a facies interpretation of this D to basement unit. It was noticed during one of the reviews of the site survey data by the JOIDES Pollution Prevention and Safety Panel that the draped and hummocky reflectors in this unit are, in some cases, apparently truncated by the basin-leveling Horizon D (Fig. 2). If such truncations are real and of an angular nature, and if the beds above the truncations happen to be sealants, such as shales, whereas those below are potential reservoir rocks, such as limestones, a hazardous situation for drilling through
Horizon D might exist. For this reason, the nature of the facies beneath Horizon D as well as the nature of possible truncations by Horizon D were critical to drilling safety.

In an attempt to resolve these uncertainties, several synthetic seismogram models were tested. One model indicated that the apparent truncations did not necessarily exist but instead a rather gradual transition with continuous deposition of beds with low dips to more horizontal beds over a 25- to 50-m thickness of sediments. This situation could not be resolved from the true erosional contact situation.

The possibility of a facies change across Horizon D instead of an erosional unconformity suggested that the other observed seismic characteristics, including asymmetric mounding and acoustic transparency, could be interpreted as preferential current deposition of clays and muds on the northern flanks of fracture-zone troughs. This interpretation, made prior to sailing on Leg 76, represents a geologic situation that is a less troublesome safety and pollution concern. If the facies below Horizon D is a claystone contourite deposited by bottom currents flowing through the fracture-zone trough, and Horizon D is a basin-leveling carbonate deposit of distal turbidites, then the situation of porous limestones (nonsealants) over claystones without reservoir potential should exist. If so, this case would not have the potential for hydrocarbon extrapment. Accordingly, the presence of contourites was predicted below Horizon D based on the seismic facies analysis.

To further test this interpretation, more postcruise synthetic seismogram modeling has been completed. Using the values for seismic interval velocities measured for the rocks in Site 534 (Fig. 3), acoustic impedance units were designed to generate the synthetic seismograms for comparison to the actual seismic profiles at Site 534. One model (Fig. 10) depicts the flat-lying $\beta, C$, and $\mathrm{D}$ reflecting units underlain by irregular hummocky

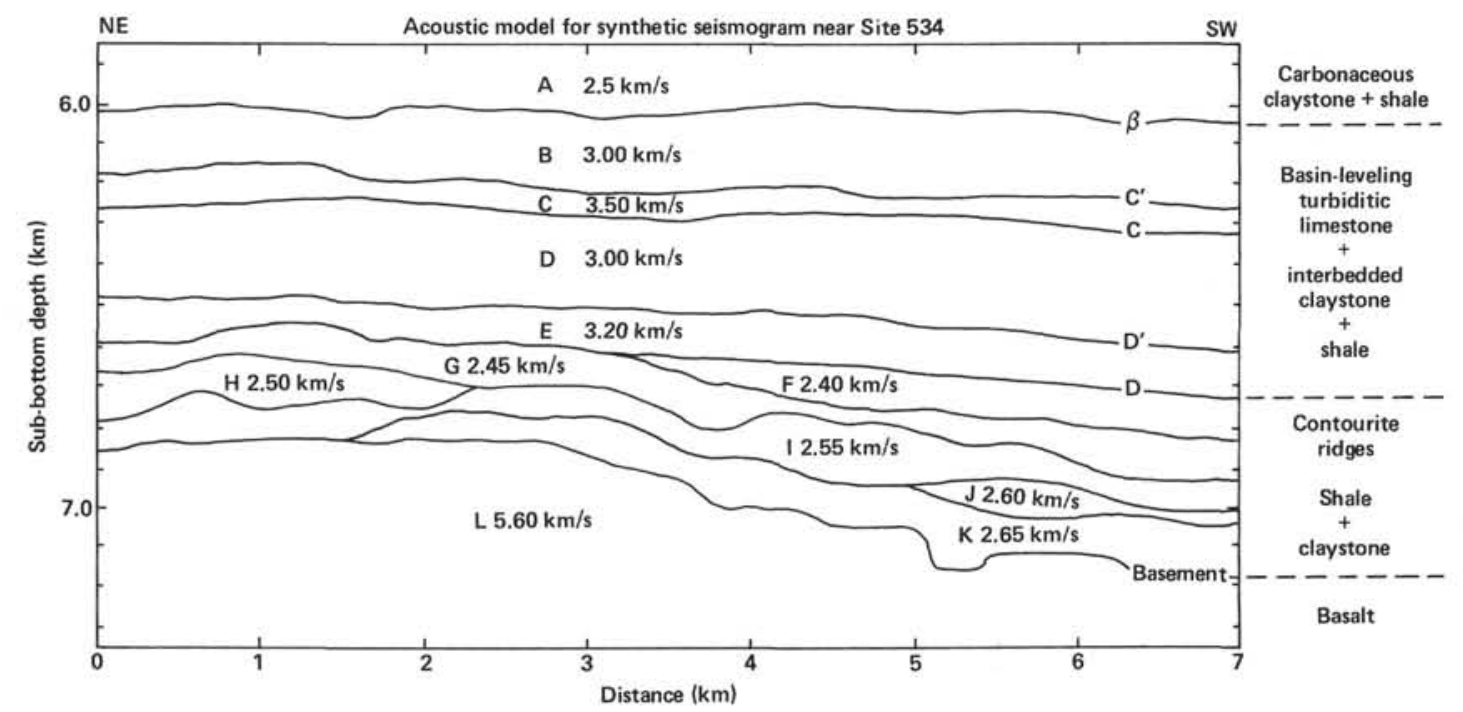

Figure 10. Model of acoustic units for the $\beta$ to basement units on the northern flank of the fracture-zone trough near Site 534. (The hummocky bed forms in the $\mathrm{D}$ to basement interval are analogous to mud-wave bed forms formed on the continental rise.) 
bed forms, which are similar in appearance to contourite mounds observed on the Blake Outer Ridge. Also, these moundlike bed forms below Horizon D appear to migrate up the northern flank of the fracture-zone trough. Note that this draping effect, if real, would indicate that the beds on the flank of the trough are the same age as those in the bottom of the trough (Fig. 10).

The velocities in the $\mathrm{D}$ to basement unit are assumed to range from 2.4 to $2.65 \mathrm{~km} / \mathrm{s}$, based on the range of velocities measured for Unit 7 at Site 534. For even small-velocity contrasts of $0.05 \mathrm{~km} / \mathrm{s}$ within the D to basement unit, the computed synthetic seismogram (Fig. 11) reveals that there are distinct, hummocky internal reflections produced. The impedance model was used to generate synthetic traces at 50-m spacing, without diffractions for simplicity in illustration and presentation. A simple positive, zero-phase pulse was then con- volved with the acoustic impedance contrast spikes for each trace. This results in a trace presentation, as if the gain over the $\beta$ to basement interval profiled was constant (Fig. 11). This presentation shows that significant internal reflections in the $\mathrm{D}$ to basement unit can occur from weak impedance contrasts in the contourite claystones.

For comparison, the time section of Line MC 89 near Site 534 (Fig. 11B) is shown at the same scale. Differences between the model and the field data include the presence of incoherent noise in the field data, and the trace equalization of the field data that mutes the larger amplitudes of the basement reflections. The field data have been deconvolved so that the reflections should approach the form of simple zero-phase wavelets.

In general there is good agreement between the synthetic seismogram model (Fig. 11A) and the field data
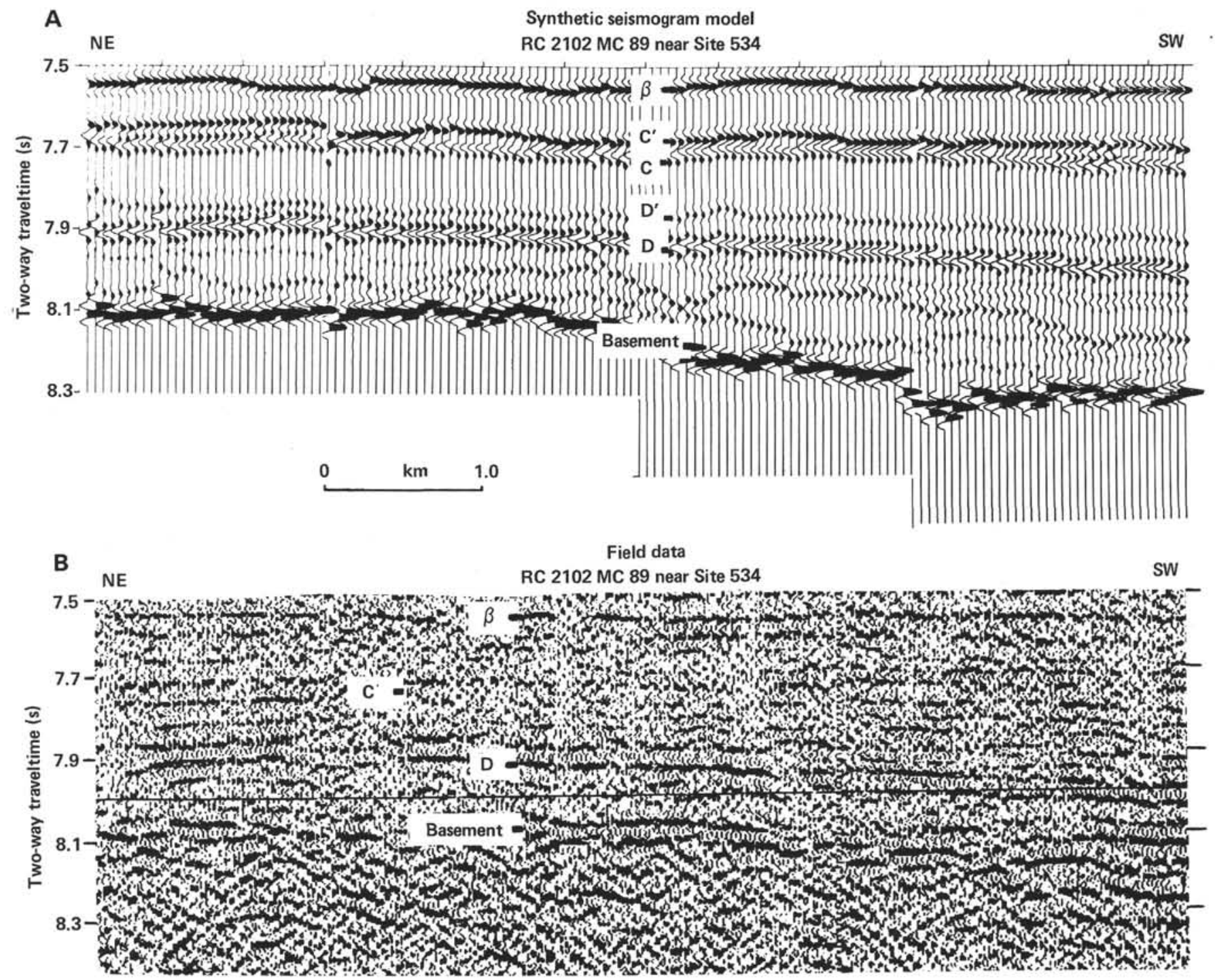

Figure 11. A. Computed synthetic seismogram showing basin-leveling reflectors $\beta, \mathrm{C}$, and $\mathrm{D}$ above the nonbasin-leveling reflectors of the $\mathrm{D}$ to basement interval. (For simplicity, random noise and diffractions are omitted.) B. Field data of profile MC 89 near Site 534 shown at the same time scale for comparison. (Note that Horizon D appears to be the lower positive shoulder of a larger-amplitude negative wavelet caused by the velocity inversion between the limestone turbidite and underlying claystone.) 
(Fig. 11B). This is supporting evidence that the $\mathrm{D}$ to basement interval is composed of nonbasin-leveling, mounded sediments. The other circumstantial evidence for the preferential deposition of these mounds by contour currents was revealed by the site survey grid of Line MC 89, which showed a consistent presence of these deposits on the north sides of the fracture-zone troughs (Figs. 12 and 13). All these factors support the interpretation that preferentially oriented bottom currents caused the mounding and draping of the sediments. The presence of deposits on the north side of the basement trough suggests that these bottom currents were flowing northwest, because the Coriolis effect would cause currents flowing in this direction to deposit sediment on the northern topographic high. This is analogous to occur- rences of preferential current deposition documented in modern fracture-zone valleys. A good example is the Amirante Passage in the Indian Ocean (Fig. 14) (Johnson and Damuth, 1979), where nearly identical seismic bed forms are observed in the recent sediments on the flanks of modern basement channels and where deposition by strong bottom currents has been documented.

\section{EVIDENCE FOR JURASSIC CONTOURITES BENEATH HORIZON D FROM SITE 534 DRILLING RESULTS}

Drilling through Horizon D at Site 534 revealed that the massive, thick carbonate turbidites do not occur below 1600-m depths in Unit 7, where the Unit 7 lithology is dominantly thin-bedded, dark-colored claystone.

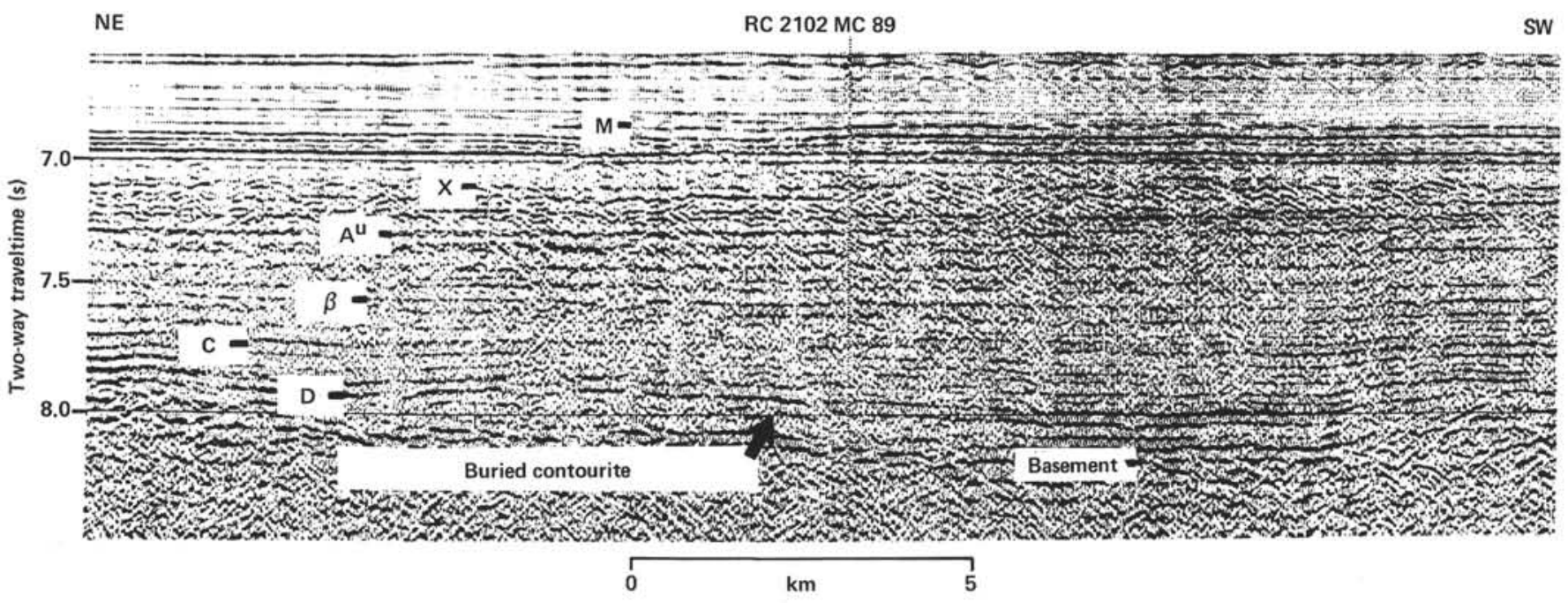

Figure 12. Time section of multichannel profile MC 89 near Site 534 showing possible contourite beds draping the north side of the fracture-zone trough. (Note how the transparent contourite beds pass laterally into well-stratified channel deposits to the south. Compare to Fig. 14.)

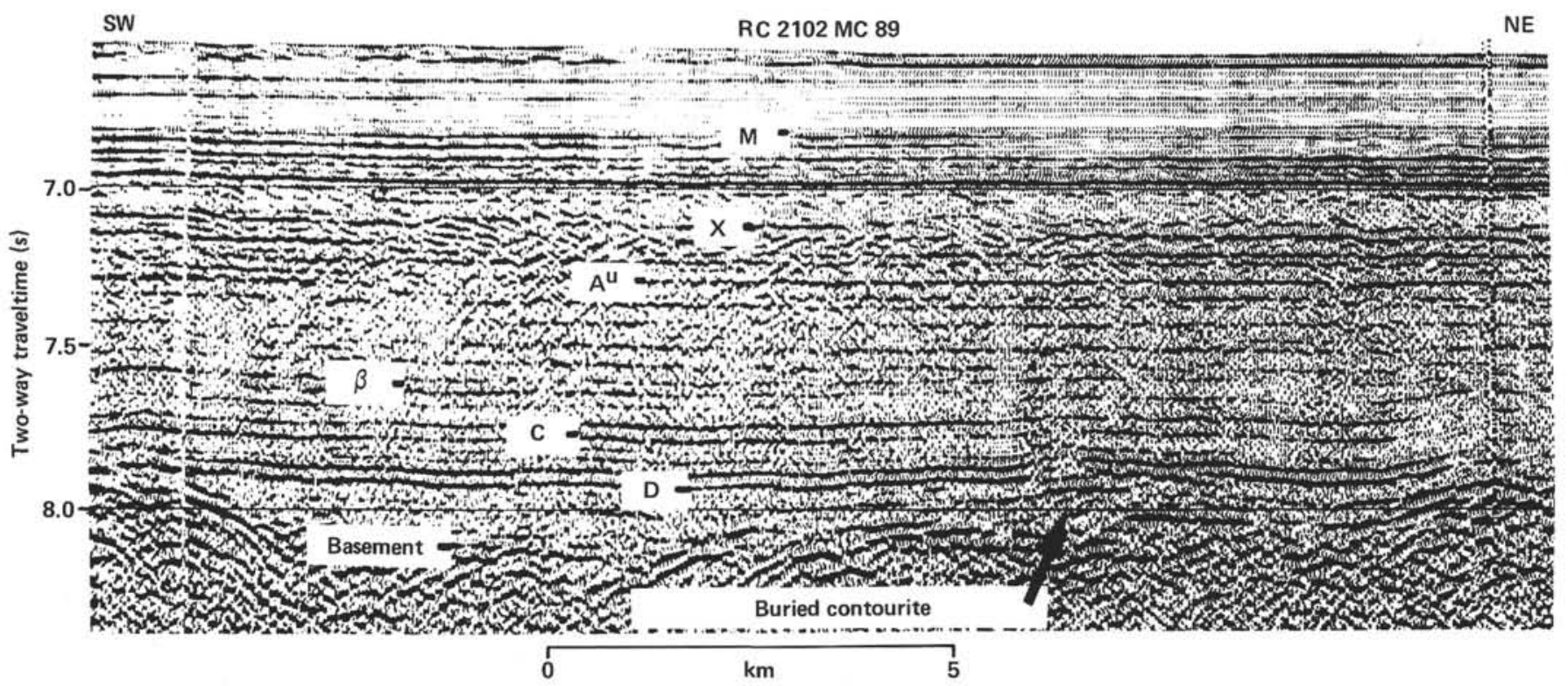

Figure 13. Time section of multichannel profile MC 89 near Site 534 showing possible contourite beds draping the north side of the fracture-zone trough. 

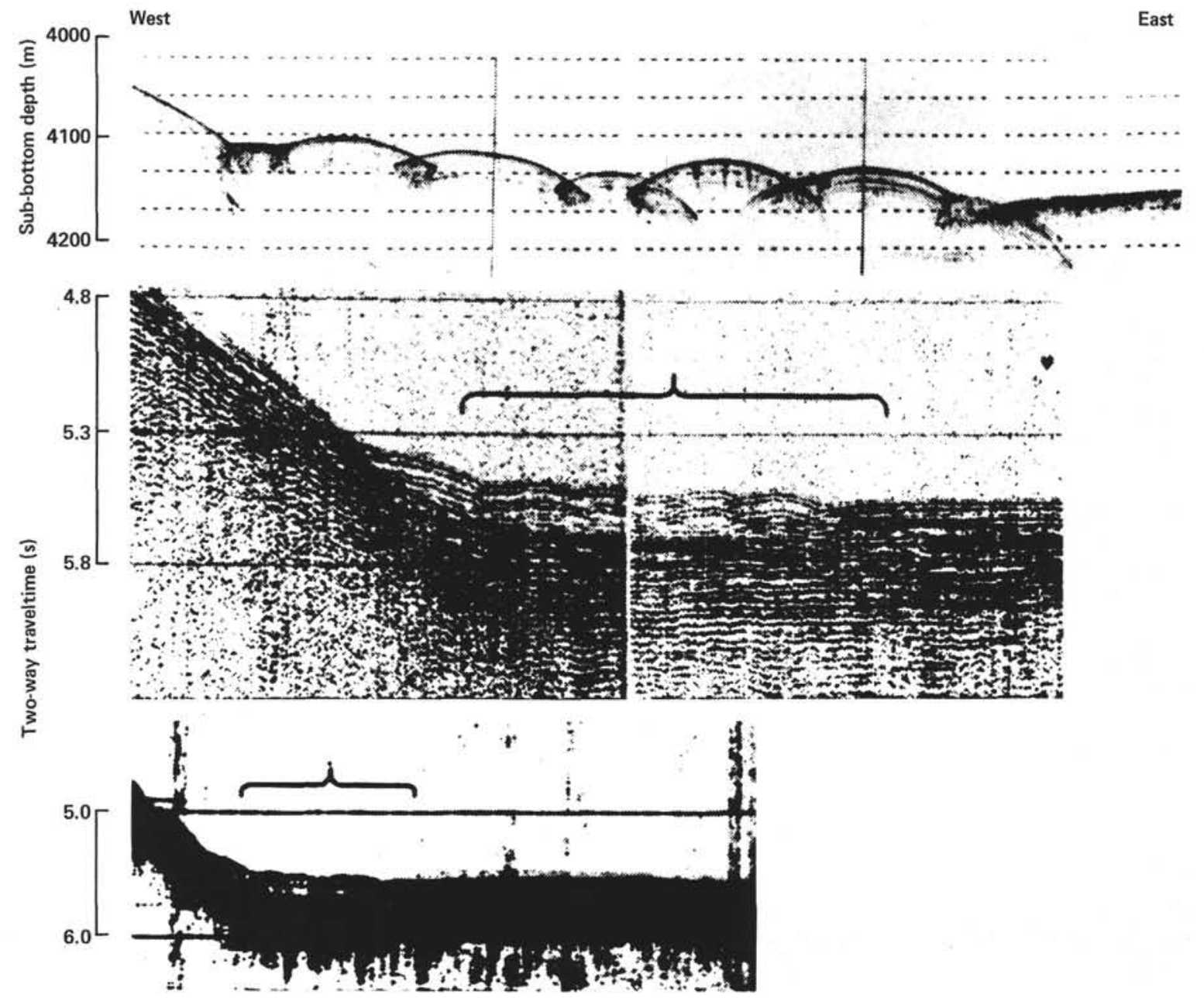

Figure 14. Sediment waves on the western flank of a narrow channel in the Amirante Passage, western Indian Ocean. (The top profile is a $3.5-\mathrm{kHz}$ echo sounding record; the lower two profiles are low-frequency seismic reflection records [ 40 -in. ${ }^{3}$ airgun source]. Note that the sediments comprising the waves are relatively transparent to both high [3.5 kHz] and low [10-100 $\mathrm{Hz}$ ] frequencies [from Johnson and Damuth, 1979]. Braces indicate the position of the $3.5-\mathrm{kHz}$ profile relative to the lower air-gun profiles. Note also that sediment waves lap into the flank of the channel as much as $0.2 \mathrm{~s}[150 \mathrm{~m}]$ shallower than the floor of the channel. Compare to Figs. 2 and 12).

Within these claystones are sedimentary structures and characteristics that indicate the presence and activity of bottom currents during the deposition of the clays. These structures include lenticular beds of starved ripples generally associated with layers of silt-size radiolarian-rich sediments that might be winnowed fossil placers; low-angle cross bedding (Fig. 15); sharp top and bottom contacts; ubiquitous laminations of various orientations; clay balls on erosional surfaces; and phosphatic crusts on erosional pavements. All these sedimentary features are compatible with and suggest bottom-current reworking. At times the currents were strong enough to erode the mud on the seafloor and to scour clean surfaces. On these surfaces, pebble-size clay clasts were apparently rolled around as a lag gravel, indicating reasonably strong currents.

Thus sedimentologic evidence from Site 534 supports the interpretation that contour currents deposited the Jurassic claystones of Unit 7. If this interpretation is correct, this would be the oldest occurrence of contourites yet documented in the existing oceans. The pale- oceanographic implications of this interpretation are significant. As a minimum statement, the interpretation of the existence of Jurassic contour currents in the western North Atlantic would be compatible with the interpretation of a rapid Jurassic opening of the Atlantic and the generation of a complicated oceanic circulation system between the Tethys and the Pacific through the newly formed Atlantic Ocean (Sheridan, this volume). Although the data presented here do not document the region-wide nature of these contour currents nor their region-wide strength, they do document some movement of the bottom water. The movement might have been sluggish over a wide region, but the topographic constrictions of the fracture zones imposed stronger local currents recorded by the contourites.

\section{SUMMARY AND CONCLUSIONS}

1. The discovery of Eocene porcellanite at Site 534 indicates the seismic reflection Horizon $\mathrm{A}^{\mathrm{c}}$ associated with this formation is merged with Horizon $\mathrm{A}^{\mathrm{u}}$ at Site 534. Horizon $\mathrm{A}^{\mathrm{u}}$ is an unconformity between Miocene 


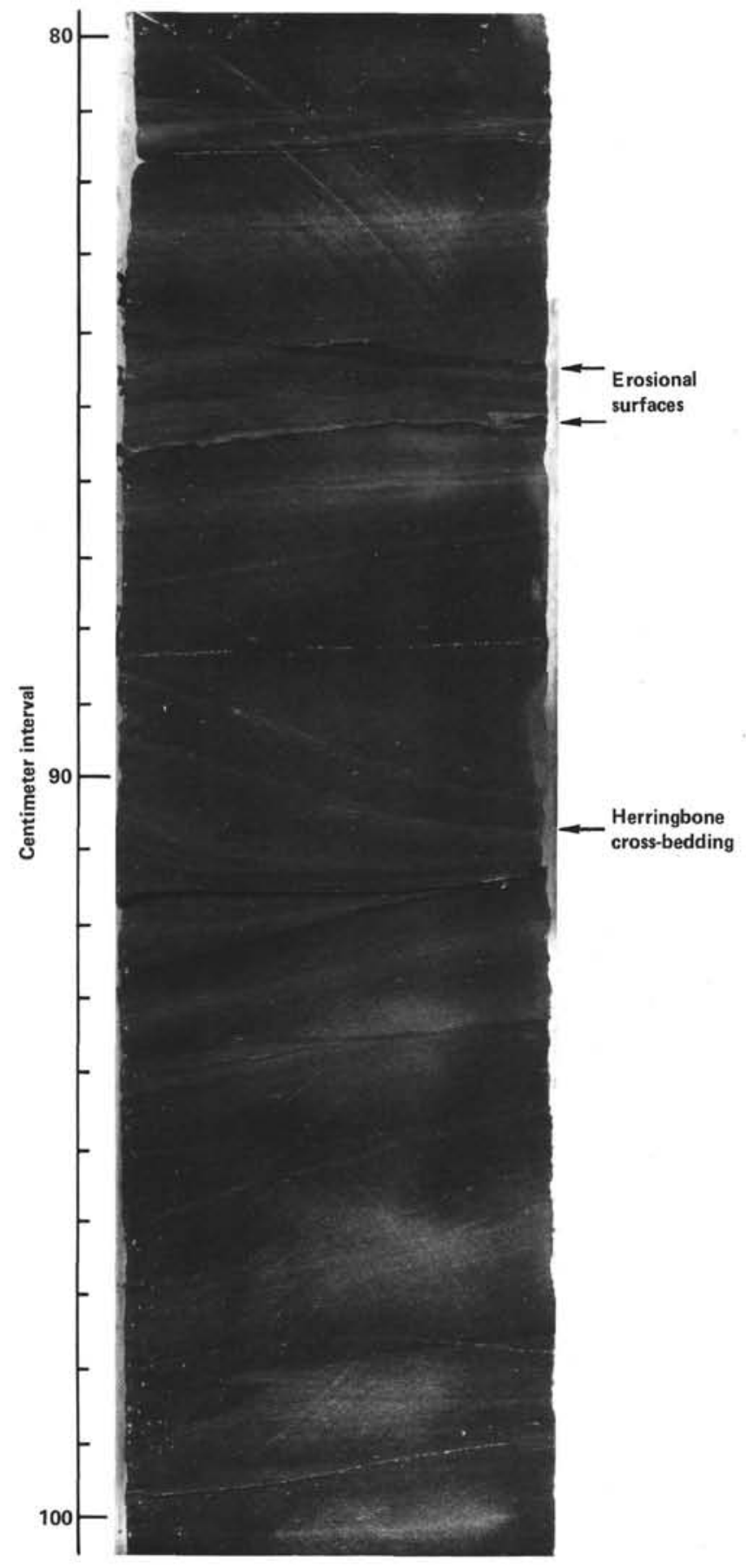

Figure 15. Core 125 (Sample 534A-125-4, 80-100 cm) showing lowangle cross-bedding in dark green claystone of unnamed Unit 7. (This is evidence of bottom-current flow during the Middle Jurassic and is compatible with the seismic facies interpretation of coutourites.)

and older rocks throughout most of the western North Atlantic.

2. In addition to $\mathbf{A}^{\mathrm{c}}$, other reflectors at Site 534 correlated with the lithologic bedding-plane impedance contrasts are Horizon $\beta$, Barremian turbiditic limestone; Horizon C, Tithonian red shaly limestone; and Horizon D, lower Oxfordian turbiditic limestone.
3. In addition to $\mathrm{A}^{\mathrm{u}}$, other reflectors at Site 534 correlated with unconformities are Horizon $\beta^{\prime}$, lower Albian-upper Aptian; Horizon $C^{\prime}$, Berriasian-Berriasian; and Horizon $\mathrm{D}^{\prime}$, Kimmeridgian-Kimmeridgian.

4. Horizon D extends seaward beyond the Blake Spur magnetic anomaly to a fingerlike pinch-out pattern near Magnetic Anomaly M-27. The fingerlike pattern is due to the transport of turbidites into ancient fracture zone troughs on the flank of the mid-ocean ridge.

5. Horizon D is equivalent to Horizon $\mathrm{J}_{2}$, which is identified and mapped north of the Blake-Bahama Ba$\sin$.

6. Horizon $\mathrm{D}$ is a basin-leveling turbidite event that overlies the nonbasin-leveling seismic reflectors at Site 534.

7. Synthetic seismogram modeling and the core data support an interpretation of contour-current deposition for the Jurassic claystones beneath Horizon D at Site 534.

8. These Jurassic contourites at Site 534 are the oldest yet identified in the oceans, and their presence is compatible with a rapid opening of the North Atlantic, and a connection of oceanic circulation between the Tethys and Pacific through the newly formed Atlantic Ocean.

\section{ACKNOWLEDGMENTS}

Much of the data and analyses presented in this chapter has been funded by various grants and contracts from NSF and JOI Incorporated. We thank J. Damuth, G. Mountain, and E. Laine for reviewing this paper.

\section{REFERENCES}

Benson, W. E., Sheridan, R. E., et al., 1978. Site 391, Blake-Bahama Basin. In Benson, W. E., and Sheridan, R. E., et al. Init. Rept. DSDP, 44: Washington (U.S. Govt. Printing Office), 153-207.

Bryan, G. M., Markl, R. G., and Sheridan, R. E., 1980. IPOD site surveys in the Blake-Bahama Basin. Mar. Geol., 35:43-63.

Buffler, R. T., Watkins, J. S., and Dillon, W. P., 1979. Geology of the offshore Southeast Georgia Embayment, U.S. Atlantic continental margin, based on multichannel seismic reflection profiles. Am. Assoc. Pet. Geol. Mem., 29:11-25.

Dillon, W. P., Paull, C. K., Buffler, R. T., and Fail, J. P., 1979. Structure and development of Southeast Georgia Embayment and Northern Blake Plateau: preliminary analysis. Am. Assoc. Pet. Geol. Mem., 29:27-41.

Dillon, W. P., Sheridan, R. E., and Fail, J. P., 1976. Structure of the western Blake-Bahama Basin as shown by 24 channel CDP profiling. Geology, 4:459-462.

Grow, J. A., and Markl, R. G., 1977. IPOD-U.S.G.S. multichannel seismic reflection profile from Cape Hatteras to the Mid-Atlantic Ridge. Geology, 5:625-630.

Jansa, L. F., Enos, P., Tucholke, B. E., Gradstein, F. M., and Sheridan, R. E., 1979. Mesoszoic and Cenozoic Sedimentary Formations in the North Atlantic Basin: western North Atlantic. Am. Geophys. Union, Maurice Ewing Series, 3:1-70.

Johnson, D. A., and Damuth, J. E., 1979. Deep thermohaline flow and current controlled sedimentation in the Amirante Passage: western Indian Ocean. Mar. Geol., 33:1-44.

Klitgord, K. D., and Grow, J. A., 1980. Jurassic seismic stratigraphy and basement structure of the western Atlantic magnetic quiet zones. Am. Assoc. Pet. Geol. Bull., 64:1658-1680.

Markl, R. G., Bryan, G. M., and Ewing, J. I., 1970. Structure of the Blake-Bahama Outer Ridge. J. Geophys. Res., 75:4539-4555.

Mountain, G. S., 1981. Seismic Stratigraphy of the Western North Atlantic [Ph.D. dissert.]. Columbia University.

Paull, C. K., and Dillon, W. P., 1980. Erosional origin of the Blake Escarpment: an alternate hypothesis. Geology, 8:538-542. 
Salvador, A., and Green, A., 1980. Opening of the Caribbean Tethys (origin and development of the Caribbean and Gulf of Mexico). Geology of the Alpine Chains Born of the Tethys. Colloque C 5, Mem. B.R.G.M., 115:224-229.

Sheridan, R. E., Crosby, J. T., Bryan, G. M., and Stoffa, P. L., 1981. Stratigraphy and structure of the southern Blake Plateau, northern Florida Straits and northern Bahama Platforms. Am. Assoc. Pet. Geol. Bull., 65:2571-2593.

Sheridan, R. E., Golovchenko, X., and Ewing, J. I., 1974. Late Miocene turbidite horizon in the Blake-Bahama Basin. Am. Assoc. Pet. Geol. Bull., 58:1797-1805.

Sheridan, R. E., Pastouret, L., and Mosditchian, G., 1978. Seismic stratigraphy and related lithofacies of the Blake-Bahama Basin. In Benson, W. E., Sheridan, R. E., et al., Init. Repts. DSDP, 44: Washington (U.S. Govt. Printing Office), 529-546.

Sheridan, R. E., Windisch, C. C., Ewing, J. I., and Stoffa, P. L., 1979. Stratigraphy and structure across the Blake Escarpment based on seismic reflection profiles. Am. Assoc. Pet. Geol. Mem., 29:177-186.

Shipley, T. H., Buffler, R. T., and Watkins, J. S., 1978. Seismic stratigraphy and geologic history of Blake Plateau and adjacent western Atlantic continental margin. Am. Assoc. Pet. Geol. Bull., 62:792-812.

Shipley, T. H., and Watkins, J. S., 1978. Fine-scale seismic stratigraphy in the western North Atlantic. Geology, 6:635-639.

Tucholke, B. E., and Mountain, G. S., 1979. Seismic stratigraphy, lithostratigraphy, and paleosedimentation patterns in the North American Basin. Am. Geophys. Union, Maurice Ewing Series, 3: 58-86.

Vail, P. R., Mitchum, R. M., Jr., Shipley, T. H., and Buffler, R. T., 1980. Unconformities of the North Atlantic. Phil. Trans. R. Soc. London, A 294:137-155.

Date of Initial Receipt: May 4, 1982 